\title{
Skurðaðgerðir við hjartapelsbólgu á Íslandi 1997-2013
}

\author{
Ragnheiður M. Jóhannesdóttir ${ }^{1}$ leknir, Tómas Guðbjartsson ${ }^{1,2}$ læknir, Arnar Geirsson ${ }^{1}$ læknir
}

\section{Á G R I P}

Inngangur: Opna hjartaaðgerð getur purft að gera í alvarlegum tilfellum hjartapelsbólgu. Tilgangur pessarar rannsóknar var að kanna árangur skurðaðgerða við hjartapelsbólgu á Íslandi en slík rannsókn hefur ekki birst áđur.

Efniviður og aðferðir: Afturskyggn rannsókn á sjúklingum sem gengust undir hjartalokuaðgerð vegna hjartapelsbólgu á Landspítala 1997-2013. Leitað̃ var að sjúklingum í rafrænum kerfum Landspítala og upplýsingar fengnar úr sjúkraskrám. Heildarlifun var reiknuð með aðferð Kaplan-Meier og var meðaleftirfylgni 7,2 ár.

Niðurstöður: Af 179 sjúklingum sem greindust með hjartapelsbólgu á rannsóknartímabilinu gengust 38 (21\%) undir skurðaðgerð. Tveimur sjúklingum var sleppt par sem sjúkraskrár peirra fundust ekki. Rannsóknarpýðið samanstóð pví af 36 sjúklingum. Aðgerðum fjölgaði jafnt og pétt á rannsóknartímabilinu, eđa úr 8 aðgerðum fyrstu 5 árin í 21 pau síđustu ((gagnlíkindahlutfall, OR - odds ratio; öryggisbil, $\mathrm{Cl}$ - confidence interval)
OR: 1,12, 95\% Cl: 1,05-1,21, p=0,002). Blóðræktanir voru jákvæðar hjá $81 \%$ sjúklinga og ræktaðist oftast S. aureus (19\%). Prír sjúklingar höfðu fyrri sögu um hjartaskurðaðgerð og 5 höfðu sögu um misnotkun fíkniefna. Algengustu staðsetningar sýkingar voru í ósæðarloku (72\%) og míturloku (28\%). Hjartaloku var skipt út i 35 tilvikum, i 14 tilvika með ólífrænni loku og i 21 tilviki með lífrænni loku. Tvær míturlokur var hægt að gera við. Algengustu fylgikvillar eftir aðgerð voru hjartadrep (35\%), öndunarbilun (44\%) og enduraðgerð vegna blæðingar (25\%). Fjórir sjúklingar létust innan 30 daga frá aðgerð (11\%) og 5 og 10 ára lifun var 59\% og $49 \%$. Umræða: Fimmti hver sjúklingur með hjartapelsbólgu á Íslandi purfti á hjartalokuaðgerð að halda, langoftast ósæðarloku- eða míturlokuskipti. Árangur er sambærilegur við erlendar rannsóknir en fylgikvillar eru tíðir, 30 daga dánartíðni hærri og langtímalifun lakari en eftir hefðbundnar lokuskiptaaðgerðir.

\section{Inngangur}

Hjartapelsbólga er blóðsýking sem leggst á hjartapel (endocardium), oftast hjartapel á hjartalokum. Petta er tiltölulega sjaldgæf sýking en samkvæmt tveimur nýlegum íslenskum rannsóknum hefur nýgengi haldist óbreytt undanfarna fjóra áratugi, eða í kringum 3/100.000 íbúa/ári. ${ }^{1,2}$ Petta er ekki ósvipað nýgengi og í erlendum rannsóknum pótt helmingi hærri nýgengistölum hafi verið lýst. ${ }^{3-5}$ Á Íslandi eru flestir sjúklinganna í kringum sextugt og karlar eru rúmlega tveir priðju hlutar sjúklinganna. ${ }^{1}$ Almennt virðist tíðnin aukast með aldri. ${ }^{6}$

Hjartapelsbólga er í hópi alvarlegustu sýkinga og dánarhlutfall er oft á bilinu 10-40\%., Tíðni er hærri hjá sjúklingum með meðfædda hjartagalla eins og tvíblöðku ósæðarloku, við áunna lokusjúkdóma eins og bakfall á aftara míturlokublaði en einnig hjá sjúklingum með gerviloku, æðaígræði eða gang- eða bjargráð. ${ }^{6}$

Einkenni hjartapelsbólgu geta verið fjölbreytileg. Í bráðri sýkingu eru hiti, hrollur og svæsin hjartabilun áberandi. Greining tefst oft hjá sjúklingum með hálfbráða sýkingu par sem einkenni eru ósértækari eins og hitavella, lystarleysi og óútskýrt pyngdartap. ${ }^{6,8}$

Einn helsti fylgikvilli hjartapelsbólgu er hjartabilun og stafar hún af leka í hjartaloku sem skemmst hefur af völdum sýkingar-

${ }^{1} H$ jarta- og lungnaskurðdeild Landspítala, ${ }^{2}$ læknadeild Háskóla Íslands.

Fyrirspurnum svarar Arnar Geirsson, arnargeirsson@yahoo.com

https://doi.org/10.17992//bl.2017.02.122

Greinin barst til blađsins 8. júní 2016, sampykkt til birtingar 12. janúar 2017. innar. ${ }^{9}$ Hjartabilun hefur mest forspárgildi um horfur sjúklings og er jafnframt algengasta dánarorsökin. ${ }^{6,10}$ Aðrir pekktir fylgikvillar eru rek á sýkingarhrúðri og myndun ígerða (abscess) sem oftast myndast við ósæðarrótina. ${ }^{11}$

Fyrsta meðferð við hjartapelsbólgu er sýklalyfjameðferð og er hún hafin um leið og blóðræktanir hafa verið teknar. Gripið er til skurðaðgerðar ef sjúklingur svarar ekki sýklalyfjameðferð. Samkvæmt erlendum rannsóknum gangast á bilinu 25-50\% sjúklinga með hjartapelsbólgu undir opna hjartaaðgerð. ${ }^{12,13}$ Við aðgerðina er sýktur vefur fjarlægður og sýktu lokunni skipt út fyrir nýja, oftast lífræna loku úr svíni eða gollurshúsi kálfs. ${ }^{14}$ Hjá yngri sjúklingum er pó stundum notast við ólífræna loku úr hertu kolefni og einstaka sinnum er hægt að gera við lokuna. ${ }^{14,15}$ Helstu ábendingar fyrir bráðaaðgerð við hjartapelsbólgu eru versnandi hjartabilun, alvarleg blóðsýking (sepsis) og stórt sýkingarhrúður á hjartalokum sem talið er geta valdið reki. ${ }^{5}$

Hér á landi hafa verið gerðar tvær rannsóknir á hjartapelsbólgu sem báđar hafa birst í Læknablaðinu., ${ }^{1,2}$ Í hvorugri pessara rannsókna var pó litið sérstaklega á árangur skurðaðgerða. Tilgangur pessarar rannsóknar var pví að skoða árangur skurðmeðferðar við hjartapelsbólgu á Íslandi með sérstaka áherslu á ábendingar fyrir aðgerð, fylgikvilla og langtímalifun.

\section{Efniviður og aðferð̄ir}

Petta er afturskyggn rannsókn sem tekur til allra sjúklinga sem gengust undir skurðaðgerð við hjartapelsbólgu frá 1. janúar 1997 til 31. desember 2013 á Landspítala. Í sjúklingabókhaldi Landspítala var leitað að sjúklingum sem fengu greininguna hjartapelsbólga 
Tafla I. Lýðfræðilegar upplýsingar um 36 sjúklinga sem gengust undir hjartaaðgerð vegna hjartapelsbólgu á Landspítala 1997-2013. Fjöldi sjúklinga og hlutfall (\%), en meðaltal með staðalfráviki og bili fyrir aldur, likamspyngdarstuðul og EuroSCORE II.

\begin{tabular}{|c|c|c|}
\hline & Fjöldi & $\%$ \\
\hline Karlar & 28 & 78 \\
\hline Aldur & $56,3 \pm 14,3$ & $(30-80)$ \\
\hline Kransæðasjúkdómur & 5 & 14 \\
\hline Háprýstingur & 15 & 43 \\
\hline Blóðfituröskun & 5 & 14 \\
\hline Sykursýki af gerð I og II & 5 & 14 \\
\hline Reykingar $(n=30)$ & 23 & 77 \\
\hline Virkar reykingar & 13 & 43 \\
\hline Tvíblöðku ósæðarloka & 9 & 25 \\
\hline Langvinn nýrnabilun & 7 & 20 \\
\hline Líkamspyngdarstuðull (kg/m²) & $27,2 \pm 4,8$ & \\
\hline Saga um fyrri hjartaskurðaðgerð & 4 & 11 \\
\hline Saga um misnotkun fíkniefna í æð & 5 & 14 \\
\hline Ónæmisbæling & 3 & 8 \\
\hline Sýkt beinígræði & 3 & 8 \\
\hline Lélegur tannstatus & 1 & 3 \\
\hline Útæðasjúkdómur & 1 & 3 \\
\hline Langvinn lungnateppa & 3 & 8 \\
\hline Heilaáfall & 6 & 17 \\
\hline EuroSCORE II & $14,0 \pm 21,0$ & \\
\hline
\end{tabular}

(ICD-10 greiningarnúmer I33.0, I33.9, I38, I39) á rannsóknartímabilinu. Sérstaklega var litið á pá sjúklinga sem purftu að gangast undir opna hjartaaðgerð vegna sýkingarinnar. Til að tryggja að sjúklingar hefðu ekki gleymst var einnig leitað аð Nordic Medico-Statistical Committee (NOMESCO) aðgerðarnúmerum fyrir skurðaðgerð á ósæðarloku (FM, FMC, FMD, FMW), míturloku (FK, FKB, FKC, FKD, FKW) og príblöðkuloku (FGC, FGD, FGE, FGW).

Alls greindust 179 sjúklingar með hjartapelsbólgu á rannsóknartímabilinu og gengust 38 (21\%) peirra undir opna hjartaaðgerð. Tveimur sjúklingum varð að sleppa par sem upplýsingar um pá fundust ekki í sjúkraskrám Landspítala. Rannsóknarpýðið samanstóð pví af 36 sjúklingum.

Klínískum upplýsingum var safnað úr sjúkraskrám og voru skráðar rúmlega 150 breytur, meðal annars aldur, kyn, hæð, pyngd, einkenni við innlögn, par á meðal hjartabilun og alvarleiki hennar metinn með New York Heart Association Functional Classification (NYHA-flokki) I-IV. Aðgerðarábending var skráð, fyrri saga um hjartaaðgerð og pá tegund inngrips, reykingar,

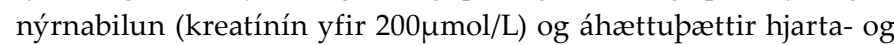
æðasjúkdóma. Athugað var hverjir voru með tvíblöðku ósæðarloku, misnotuðu eða höfðu misnotað fíkniefni í æð, saga um ónæmisbælandi sjúkdóma eða ónæmisbælandi meðferð (til dæmis barkstera). Pá var skráð hversu langur tími leið frá greiningu hjartapelsbólgu að aðgerð, ástand sjúklingsins fyrir aðgerð, hvort um bráðaaðgerð var að ræða, niðurstöður blóðræktana og hvaða sýklalyf voru gefin fyrir og eftir aðgerð.
Tafla II. Einkenni og myndgreiningaraðferðir 36 sjúklinga sem gengust undir hjartaskurðaðgerð vegna hjartapelsbólgu á Íslandi 1997-2013. Fjöldi og hlutfall (\%).

\begin{tabular}{lcc}
\hline & Fjöldi & $\%$ \\
\hline Hiti $(\mathrm{n}=33)$ & 27 & 82 \\
\hline Mæði $(\mathrm{n}=29)$ & 24 & 86 \\
\hline Pyngdartap & 10 & 28 \\
\hline Hjartabilun (n=33) & 26 & 79 \\
\hline NYHA-flokkur IV & 14 & 42 \\
\hline Lungnaháprýstingur & 6 & 17 \\
\hline Sýkingarhrúður á hjartaloku & 16 & 44 \\
\hline Hjartaómskoðun & 36 & 100 \\
\hline Frá brjóstvegg & 36 & 100 \\
\hline Frá vélinda & 31 & 86 \\
\hline Kransæðapræðing & 22 & 60 \\
\hline Jákvæð blóðræktun & 29 & 81 \\
\hline Tölvusneiðmyndataka af brjóstholi & 7 & 19 \\
\hline Segulómskoðun af brjóstholi & 1 & 3 \\
\hline
\end{tabular}

Kannað var hvaða myndrannsóknir voru framkvæmdar fyrir aðgerð; par með talið vélindaómskoðun, tölvusneiðmyndataka, segulómskoðun og hjartapræðing. Svör úr hjartaómskoðun fyrir aðgerð voru yfirfarin; útstreymisbrot vinstri slegils skráð og hvort leki eða prenging væri til staðar í lokunni. Einnig var athugað sérstaklega hvort sýkingarhrúður hefði sést á lokublaði eða hvort ígerð væri til staðar við lokuna. EuroSCORE II var reiknað fyrir alla sjúklinga fyrir aðgerð, en pað er áhættulíkan sem metur líkur á dauða sjúklinga á fyrstu 30 dögum frá aðgerð. ${ }^{16}$

Aðgerðum var skipt í lífsbjargandi (emergency), bráða (acute) og áríðandi (subacute). Lífsbjargandi aðgerð var skilgreind sem aðgerð framkvæmd innan 24 klukkustunda frá ákvörðun um aðgerð og sjúklingum ekki hugað líf án inngrips. Bráð aðgerð var hins vegar gerð innan viku frá ákvörðun og áríðandi aðgerð ýmist pegar sjúklingar höfðu verið viku eða lengur á sýklalyfjum eða höfðu lokið sýklalyfjameðferð.

Aðgerðirnar voru framkvæmdar í gegnum bringubeinsskurð, notuð hjarta- og lungnavél og hjartað stöðvað. Skráð var tímalengd á hjarta- og lungnavél en einnig tangartími (cross-clamp time) í mínútum.

Fylgikvillum var skipt í alvarlega og minniháttar en til peirra fyrrnefndu töldust: hjartadrep í aðgerð (skilgreint sem hæsta gildi CK-MB yfir 70 mg/L), enduraðgerð vegna blæðingar, öndunarbilun par sem pörf var á öndunarvél í meira en 48 klukkustundir með eða án barkaraufunar, heilaæðaáfall, fjöllíffærabilun, djúp sýking í bringubeini og bráður nýrnaskaði sem krafðist blóðskilunar. Minniháttar fylgikvillar voru gáttatif/flökt, lungnabólga, yfirborðssýking í skurðsári, nýrnaskaði par sem blóðskilunar var ekki pörf, pvagfærasýking, gjörgæslutaugakvilli (intensive care neuropathy) og fleiðruvökvi sem krafðist aftöppunar.

Blæðing fyrstu 24 klukkustundirnar eftir aðgerð var skráð í millilítrum (mL) og jafnframt hversu mikið var gefið af blóðhlutum í sjúkrahúslegunni í einingum. Legutími á gjörgæslu og á legudeild hjarta- og lungnaskurðlækninga var skráður í dögum. 
Tafla III. Fjöldi og hlutfall sjúklinga (\%) með hjartabelsbólgu sem gengust undir hjartaaðgerð á Landspítala 1997-2013 og fengu sýklalyfjameðferð. Sjúklingar gátu verið á fleiri en einu lyfi samtímis.

\begin{tabular}{lcc}
\hline Tegund sýklalyfs & Fjöldi & $\%$ \\
\hline Priðju kynslóðar kefalosporín & 20 & 56 \\
\hline Penisillínasa-polin penisillín & 18 & 50 \\
\hline Vancomycín & 15 & 42 \\
\hline Penisillín & 14 & 39 \\
\hline Gentamicín & 13 & 36 \\
\hline Carbapenem & 4 & 11 \\
\hline Flúrókínolón & 4 & 11 \\
\hline Fyrstu kynslóðar kefalosporín & 3 & 8 \\
\hline Rifampín & 3 & 8 \\
\hline Trimetoprim/súlfa & 1 & 3 \\
\hline Daptomycín & 1 & 3 \\
\hline Linezolíd & 1 & 3 \\
\hline Tetracyklín & 1 & 3 \\
\hline
\end{tabular}

\section{Tölfræðiúrvinnsla}

Upplýsingar voru skráðar í Microsoft Office Excel útgáfu 2011 (Microsoft, Redmond WA) og lýsandi tölfræði unnin í pví. Tölfræðipróf voru unnin í forritinu Prism (Graphpad, La Jolla CA) par sem tvípáttabreytum var lýst sem hlutföllum (\%) og línulegum breytum með meðaltali, miðgildi og staðalfráviki. Til að meta árlegan fjölda aðgerða var gerð Poisson-aðhvarfsgreining og reiknað gagnlíkindahlutfall með 95\% öryggisbil. Marktæki miðast við tvíhliða p-gildi $<0,05$. Langtímalifun var áætluð með aðferð Kaplan-Meier og fengust upplýsingar um dánardag úr Dánarmeinaskrá Embættis landlæknis. Eftirlit miðast við 31. desember 2013 og var meðaleftirfylgni 7,2 ár (bil: 0-14,5).

Áður en rannsóknin hófst fengust öll tilskilin leyfi frá vísindasiðanefnd, Persónuvernd og framkvæmdastjóra lækninga á Landspítala.

\section{Niðurstödur}

Sjúklingaupplýsingar

Í töflu I eru helstu lýðfræðilegar upplýsingar um sjúklingana. Meðalaldur var $56 \pm 14$ ár og var yngsti sjúklingurinn 28 ára og sá

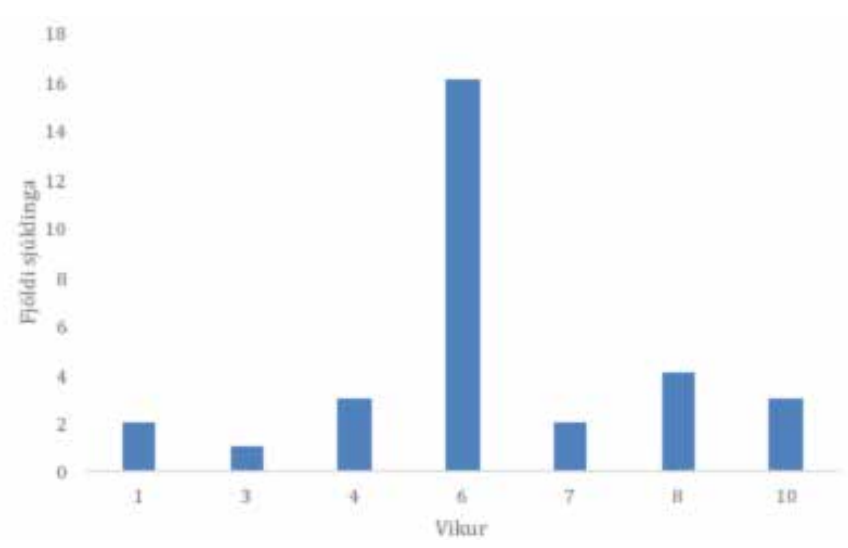

Mynd 1. Lengd sýklalyfjameðferðar í vikum fyrir og eftir aðgerð, og fjöldi sjúklinga. elsti 80 ára. Karlar voru 28 (77\%) talsins, 9 sjúklingar (25\%) höfðu tvíblöðku ósæðarloku, 5 (14\%) höfðu sögu um misnotkun fíkniefna í æð og 23 (77\%) höfðu einhvern tíma reykt. Kransæðasjúkdómur var pekktur hjá 5 sjúklingum (14\%), háprýstingur hjá 15 (43\%), sykursýki hjá öðrum 5 (15\%) og nýrnabilun hjá 7 (20\%) sjúklingum. Prír sjúklingar höfðu áður gengist undir lokuskiptaaðgerð, tveir á ósæðarloku og einn á míturloku. Tvær af pessum lokum voru lífrænar og ein ólífræn. EuroSCORE II var að meðaltali $20 \pm 21$ (bil: $0,9-97,8)$.

\section{Einkenni sjúklinga fyrir aðgerð}

Tafla II sýnir einkenni sjúklinga fyrir aðgerð en algengust voru mæði (83\%) og hiti (82\%). Tíu sjúklingar (28\%) höfðu oútskýrt pyngdartap fyrir aðgerð. Einkenni hjartabilunar voru til staðar hjá 26 (79\%) sjúklingum og voru pau metin í NYHA-flokki IV hjá $42 \%$ peirra. Allir sjúklingar gengust undir ómskoðun af hjarta frá brjóstvegg ( $\mathrm{n}=36)$, en 33 sjúklingar að auki um vélinda. Kransæðapræðing var gerð hjá 22 sjúklingum (61\%) fyrir aðgerð og fannst marktækur kransæðasjúkdómur hjá 7 peirra.

\section{Sýklaræktanir}

Blóðræktanir reyndust jákvæðar hjá 29 sjúklingum (81\%) og af peim 32 lokum sem sendar voru í ræktun eftir aðgerðina reyndust 7 (22\%) jákvæðar. Gram-jákvæðir kokkar voru algengustu sýkingarvaldarnir, eða í 82\% tilfella, en par á eftir komu gram-jákvæðir stafir (11\%). Aðrir sýkingarvaldar voru sjaldgæfari og enginn sjúklingur hafði sveppasýkingu í blóði. Í premur tilfellum (8\%) reyndist hvorki blóðræktun né ræktun frá loku sem fjarlægð var í aðgerð jákvæð.

\section{Sýklalyfjameðferð og tími að aðgerð}

Tímalengd sýklalyfjagjafar fyrir aðgerð var að meðaltali $4,4 \pm$ 5,2 vikur (bil 1-10) (tafla III, mynd 1). Tólf sjúklingar (33\%) gengust undir lífsbjargandi aðgerð, 13 (36\%) undir bráðaaðgerð og 11 (31\%) gengust undir áríðandi aðgerð. Tímalengd frá greiningu að skurðaðgerð var allt frá samdægurs til 593 daga, en miðgildið var 12 dagar (bil: 0-593). Sá sem beið lengst eftir aðgerð var tæplega prítugur karlmaður sem misnotaði fíkniefni í æð en hann gat ekki hætt neyslu prátt fyrir endurteknar sýkingar. Purfti að taka hann í bráðaaðgerð vegna alvarlegrar hjartabilunar sem stafaði af miklum ósæðarlokuleka.

\section{Hlutfall sýktra hjartaloka og aðgerðir}

Ósæðarlokan var sú loka sem sýktist í flestum tilvikum, eða hjá 26 (72\%) sjúklingum. Höfðu 9 (35\%) peirra tvíblöðkuloku og tveir (8\%) ígrædda ósæðarloku par sem ein var lífræn og hin ólífræn. Ígerð í ósæðarrót var til staðar hjá 12 pessara sjúklinga. Ósæðarlokunum var alltaf skipt út og fengu 16 sjúklingar lífræna gerviloku en 10 ólífræna. Fimm sjúklingar gengust undir kransæðahjáveituaðgerð samtímis ósæðarlokuskiptum og 5 sjúklingar undir viðgerð á príblöðkuloku (n=3) eða míturloku (n=2). Míturloka var sýkt hjá 10 sjúklingum, en í einu pessara tilfella var um sýkta ólífræna gervi- 
Tafla IV. Aðgerð, aðgerðarupplýsingar og tegund gerviloku. Fjöldi sjúklinga og hlutfall (\%), en meðaltöl með staðalfráviki og bil fyrir tímalengd frá greiningu, vélar- og tangartíma. Upplýsingar um lokur, og einn sjúklingur gekkst bæði undir lokuskipti á ósæðar- og míturloku.

\begin{tabular}{|c|c|c|}
\hline & Fjöldi & $\%$ \\
\hline Lífsbjargandi aðgerð & 12 & 33 \\
\hline Bráð aðgerð & 13 & 36 \\
\hline Áríðandi aðgerð & 11 & 31 \\
\hline Tími frá greiningu að aðgerð (dagar) & $12 \pm 80$ & $(0-593)$ \\
\hline Aðgerð á ósæðarloku & 26 & 72 \\
\hline Lífræn gerviloka ( $n=26)$ & 16 & 62 \\
\hline Ólífræn gerviloka & 10 & 38 \\
\hline Hjáveituaðgerð samtímis & 5 & 19 \\
\hline Önnur lokuaðgerð samtímis & 5 & 19 \\
\hline Vélartími (mínútur) & $163 \pm 77$ & (73-382) \\
\hline Tangartími (mínútur) & $119 \pm 56$ & $(57-273)$ \\
\hline Míturloka & 10 & 28 \\
\hline Lífræn gerviloka $(n=10)$ & 4 & 40 \\
\hline Ólífræn gerviloka & 4 & 40 \\
\hline Viðgerð á loku & 2 & 20 \\
\hline Hjáveituaðgerð samtímis & 2 & 20 \\
\hline Önnur lokuaðgerð samtímis & 1 & 10 \\
\hline Vélartími (mínútur) & $153 \pm 44$ & $(103-215)$ \\
\hline Tangartími (mínútur) & $109 \pm 38$ & $(62-163)$ \\
\hline Príblöðkuloka & 1 & 3 \\
\hline Lífræn gerviloka ( $n=1$ ) & 1 & 100 \\
\hline Vélartími (mínútur) & 74 & \\
\hline Tangartími (mínútur) & 51 & \\
\hline
\end{tabular}

loku að ræða. Hjá 8 sjúklingum var skipt um míturlokuna, í fjórum tilfellum með lífrænni gerviloku og í hinum fjórum með ólífrænni gerviloku. Hjá tveimur sjúklingum reyndist unnt að gera við míturlokuna. Hjáveituaðgerð var gerð samtímis hjá einum sjúklingi og hjáveituaðgerð ásamt viðgerð á príblöðkuloku hjá öðrum sjúklingi. Í einu tilfelli var um sýkta príblöðkuloku að ræða en sá sjúklingur hafði sögu um misnotkun fíkniefna í æð. Var lokunni skipt út fyrir lífræna gerviloku (tafla IV). Aðgerðum fjölgaði jafnt og pétt á rannsóknartímabilinu, eða úr 8 aðgerðum fyrstu 5 árin í 21 pau síðustu ((gagnlíkindahlutfall, OR - odds ratio; öryggisbil, CI - confidence interval) OR: 1,12, 95\% CI: 1,05-1,21, p=0,002).

\section{Blæðing og blóðhlutagjafir}

Blæðing fyrstu 24 klukkustundirnar í brjóstholskera og magn blóðhluta sem gefnir voru eftir aðgerð (í sömu sjúkrahússlegu) er sýnt í töflu V. Heildarblæðing var $870 \pm 3730$ mL, (bil: 230-20865). Alls fengu 28 af 34 sjúklingum (82\%) einhverja blóðhluta, oftast rauðkornapykkni, eða að meðaltali 4,0 $\pm 13,6$ einingar (bil: 1-65), blóðvatn $(4,0 \pm 22,8$ einingar, bil: 0-117) og blóðflögur $(2,5 \pm 2,2$ poka, bil: 0-9).
Tafla V. Blæðing og notkun blóðhluta, meðaltöl með staðalfráviki og bili.

\begin{tabular}{lcc}
\hline & Meðaltal & Bil \\
\hline Heildarblæðing $(\mathrm{mL})$ & $870 \pm 3730$ & $230-20865$ \\
\hline Rauðkornapykkni (ein) & $4,0 \pm 13,6$ & $1-65$ \\
\hline Plasma (ein) & $4,0 \pm 22,8$ & $0-9$ \\
\hline Blóðflögur (pokar) & $2,5 \pm 2,2$ & $0-117$ \\
\hline
\end{tabular}

Fylgikvillar eftir aðgerð

Fylgikvillar eftir aðgerð eru sýndir í töflu VI. Alvarlega fylgikvilla fengu $61 \%$ sjúklinga, en efst á blaði var hjartadrep sem greindist hjá 35\% sjúklinga. Síðan komu enduraðgerð vegna blæðingar (26\%), öndunarbilun (43\%) par sem í helmingi tilfella purfti barkaraufun (tracheostomy), fjöllíffærabilun (20\%) og bráður nýrnaskaði sem krafðist blóðskilunar (17\%). Einn sjúklingur (3\%) purfti enduraðgerð vegna sýkingar í nýju lokunni og var skipt um hana, en enginn greindist með miðmætisbólgu eða djúpa sýkingu í bringubeini. Minniháttar fylgikvillar greindust hjá $64 \%$ sjúklinga og var gáttaflökt algengast (56\%). Aðrir minniháttar fylgikvillar eru sýndir í töflu VI.

\section{Legutími og lifun}

Heildarlegutími var að meðaltali $55 \pm 52$ dagar (miðgildi: 43 dagar, bil: 7-222), par af $11 \pm 18$ (miðgildi 4 dagar, bil: 1-85) dagar á gjörgæslu.

Fjórir sjúklingar (11\%) létust innan 30 daga frá aðgerð. Einn pessara sjúklinga lést í aðgerð og var dánarorsök hans samkvæmt krufningu svæsin sýklasótt með fjöllífærabilun. Annar sjúklingur var kona á sextugsaldri sem lést vegna rifu á afturvegg hjarta, en rof kom á hjartað eftir míturlokuskipti vegna sýkingar á aftara míturlokublaði. Priðji sjúklingurinn sem lést var karlmaður, einnig á sextugsaldri, sem fékk heilaáfall frá sýkingarhrúðri sem hafði losnað frá ósæðarloku og valdið reki. Fjórði sjúklingurinn var karlmaður á sjötugsaldri sem lést vegna hjartabilunar og bráđrar lungnabólgu. Fyrir aðgerð hafði hann mikinn ósæðarlokuleka og aðeins $25 \%$ útfall á vinstri slegli.

Mynd 2 sýnir langtímalifun en heildarlifun eftir aðgerð (Kaplan-Meier) var 59\% eftir 5 ár og 50\% 10 árum frá aðgerð.

\section{Umræður}

Á rannsóknartímabilinu sem tók til 16 ára greindust samtals 179 tilfelli af hjartapelsbólgu á Landspítala. Svipuðu nýgengi hefur verið lýst erlendis pótt í mörgum rannsóknum sé pað allt að tvöfalt hærra. ${ }^{5}$ Nýgengi hjartapelsbólgu í mismunandi rannsóknum ræðst af ýmsum páttum, meðal annars aldurssamsetningu sjúklinganna og algengi meðfæddra hjartagalla. Samkvæmt íslenskum rannsóknum eru helstu áhættupættir hjartapelsbólgu hér á landi meðfæddur hjartagalli (aðallega tvíblöðku ósæðarloka) og ígrædd hjartaloka en einnig fíkniefnamisnotkun, hrörnunarbreytingar í hjartaloku og léleg tannhirða. Gigtsótt (febris rheumatica) er hins vegar mjög sjaldgæf ástæða hjartapelsbólgu á Íslandi líkt og hún er fyrir lokuskipti almennt., ${ }^{1,17}$ 
Tafla VI. Fylgikvillar, alvarlegir og minniháttar, eftir aðgerð. Fjöldi og hlutfall (\%).

\begin{tabular}{|c|c|c|}
\hline & Fjöldi & $\%$ \\
\hline \multicolumn{3}{|l|}{ Alvarlegir fylgikvillar } \\
\hline Enduraðgerð vegna blæðingar $(n=35)$ & 9 & 26 \\
\hline Hjartadrep $(n=34)$ & 12 & 35 \\
\hline Öndunarbilun (n=35) & 15 & 43 \\
\hline Barkaraufun $(n=35)$ & 8 & 23 \\
\hline Blóðskilun (n=35) & 6 & 17 \\
\hline Heilaáfall $(n=35)$ & 5 & 14 \\
\hline Djúp sýking í bringubeini & 0 & \\
\hline Enduraðgerð vegna sýkingar & 1 & 3 \\
\hline Fjöllíffærabilun (n=35) & 7 & 20 \\
\hline Allir alvarlegir fylgikvillar samanlagt & 22 & 61 \\
\hline \multicolumn{3}{|l|}{ Minniháttar fylgikvillar } \\
\hline Nýtilkomið gáttatif/gáttaflökt & 20 & 56 \\
\hline Lungnabólga $(n=35)$ & 10 & 29 \\
\hline Aftöppun fleiðruvökva ( $n=35)$ & 8 & 23 \\
\hline Nýrnaskilun á gjörgæslu (Prisma ${ }^{\circledR}(n=35)$ & 8 & 23 \\
\hline Gjörgæslutaugakvilli (n=35) & 3 & 9 \\
\hline Pvagfærasýking (n=35) & 4 & 11 \\
\hline Yfirborðssýking í bringubeinsskurði & 1 & 3 \\
\hline Allir minniháttar fylgikvillar samanlagt & 23 & 64 \\
\hline Dáinn í aðgerð & 1 & 3 \\
\hline Dánir innan 30 daga & 4 & 11 \\
\hline
\end{tabular}

Rúmlega fimmtungur sjúklinga sem greindir voru með hjartapelsbólgu á rannsóknartímabilinu gengust undir opna hjartaskurðaðgerð. Eftir pví sem leið á rannsóknartímabilið gengust fleiri sjúklingar undir aðgerð. Petta er pó heldur lægra hlutfall en í flestum erlendum rannsóknum, par sem hlutfallið er oftast á bilinu 25-57\%. Í spænskri rannsókn frá árunum 1987-1997 var sýnt að 50\% sjúklinga með hjartapelsbólgu gengust undir hjartaskurðaðgerð. ${ }^{12}$ Pá var hlutfallið 50\% í stórri samevrópskri rannsókn sem náði til rúmlega 5000 sjúklinga með rannsóknartímabilið frá apríl til júlí 2001. ${ }^{13}$ Í stórri framskyggnri fjölpjóðarannsókn sem kallast ICE-PLUS (The International Collaboration on Endocarditis-PLUS) gengust 57\% undir aðgerð við hjartapelsbólgu og var rannsóknartímabilið frá 1. september 2008 til 31. desember 2012.18 Í ICE-PLUS rannsókninni var borin saman 6 mánaða lifun veikustu sjúklinganna eftir pví hvort peir fengu skurðmeðferð eða einungis meðferð með sýklalyfjum og kom í ljós að lifun peirra sem gengust undir aðgerð var marktækt betri. ${ }^{18}$

\section{Ábendingar fyrir aðgerð}

Við ákvarðanatöku um pað hvort sjúklingur ætti að gangast undir aðgerð var stuðst við klínískar evrópskar leiðbeiningar. ${ }^{5} \mathrm{Al}-$ gengasta ábending pess að sjúklingar með hjartapelsbólgu voru teknir til aðgerðar var mikill ósæðar- eða míturlokuleki sem olli bráðri hjartabilun. Sextán sjúklingar (44\%) höfðu sýkingarhrúður á hjartalokum sem varð til pess að aðgerð var flýtt og með

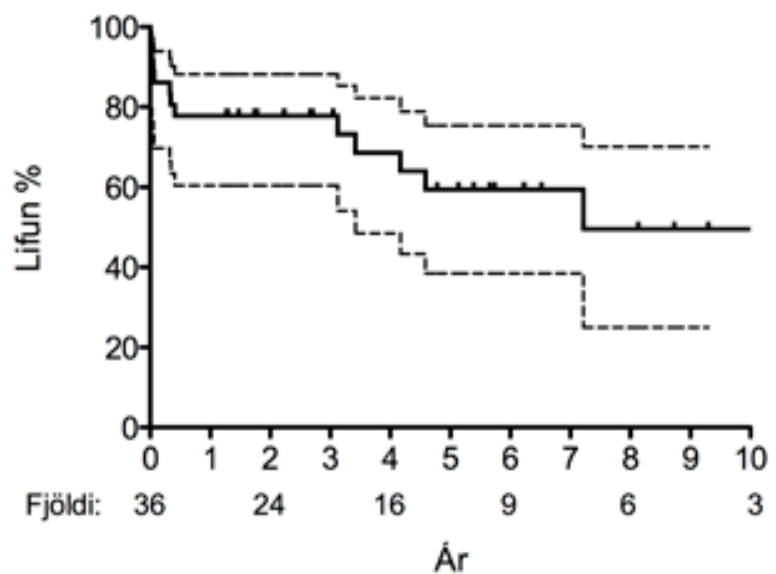

Mynd 2. Аðgerð, aðgerðarupplýsingar og tegund gerviloku, fjöldi sjúklinga og hlutfall. Meðaltöl með staðalfráviki eru gefin upp fyrir timalengd frá greiningu og vélar- og tangartíma. Einn sjúklingur gekkst undir lokuskipti bæði á ósæðar-og míturloku.

pví reynt að forða peim frá heilaáfalli. Sumir pessara sjúklinga höfðu bæði sýkingarhrúður á lokunni og lokuleka, sem flýtti enn frekar fyrir aðgerð. Prettán (36\%) sjúklingar greindust með heilaáfall fyrir aðgerð og lést einn peirra innan 30 daga frá aðgerð. Í erlendum rannsóknum er talið að hjá priðjungi sjúklinga með hjartapelsbólgu losni sýkingarhrúður og reki til annarra líffæra, en í tveimur priðju pessara tilfella er um að ræða rek til heila sem veldur einkennum frá miðtaugakerfi. ${ }^{13}$ Rek vegna sýkingarhrúðurs er jafnframt önnur algengasta dánarorsök sjúklinga með hjartapelsbólgu, á eftir hjartabilun. ${ }^{719}$ Heilaáfall vegna reks er einn af alvarlegustu og algengustu fylgikvillum hjartapelsbólgu. Áhættupættir reks er sýking í ósæðar- eða míturloku par sem stórt sýkingarhrúður myndast á lokublaði. S. aureus er pekkt fyrir að mynda auðveldlega sýkingarhrúður. ${ }^{13}$ Hætta á reki er mest fyrstu tvær vikurnar eftir að sjúklingur veikist. ${ }^{13}$ Í okkar rannsókn voru 10 einstaklingar (28\%) sem fengu rek til heila og ekki annarra líffæra. Sex sjúklingar fengu rek á sýkingarhrúðri til annarra líffæra, til dæmis út í fætur, hendur, kransæðar, augu, nýra og milta og einn peirra greindist með Janeway-bletti í lófum. Af pessum 6 sjúklingum fengu prír rek til heila.

Ábendingar fyrir skurðaðgerð í hjartapelsbólgu eru skýrar samkvæmt klínískum leiðbeiningum, en meta parf hvert tilfelli fyrir sig. ${ }^{5}$ Hvað varðar mat á stærð á sýkingarhrúðri er mælt með aðgerð sé pað yfir $15 \mathrm{~mm}$ að stærð. Hafi pegar orðið rek er mælt með aðgerð sé sýkingarhrúður yfir $10 \mathrm{~mm}$ að stærð. ${ }^{5}$ Áður var talin hætta á blæðingu í blóðpurrðarsvæði en rannsóknir hafa sýnt að blæðingarhættan er lítil og að horfur eru almennt taldar betri ef aðgerð er gerð fyrr en síðar í sjúkdómsferlinu. ${ }^{20}$

\section{Sýkingarvaldar og sýklalyfjagjöf}

Algengustu sýkingarvaldar peirra sem gengust undir aðgerð samkvæmt ræktunum voru gram-jákvæðir kokkar með S. aureus efstan á blaði (19\% tilfella) líkt og í fjölda erlendra rannsókna. ${ }^{21}$ Til samanburðar var S. aureus einnig algengasti sýkingarvaldur (19\%) í íslenskri rannsókn á hjartapelsbólgu en sú rannsókn náði einnig til sjúklinga sem ekki fóru í aðgerð. ${ }^{1}$ S. aureus er pekktur fyrir 
að valda bráðum sýkingum og er sjúkdómsgangur oft hraður með skemmdum á lokublöðum og ígerðamyndun. ${ }^{13}$ Sökum pessa eru sjúklingar með $S$. aureus-sýkingu oft teknir snemma til aðgerðar. ${ }^{22}$

Frekar hátt hlutfall sjúklinga með sögu um misnotkun fíkniefna í æð gengust undir skurðaðgerð (14\%). Í íslensku rannsókninni á hjartapelsbólgu höfðu $18 \%$ pýðisins sögu um misnotkun fíkniefna í æð. ${ }^{1}$ Erlendis er petta hlutfall í kringum 2-5\%. Skýringin á pessu er ekki augljós en hugsanlega gæti gott aðgengi pessara sjúklinga að heilbrigðispjónustu verið hluti af skýringunni. ${ }^{1,23,24}$

Tímalengd sýklalyfjagjafar teygði sig allt frá einni og upp í 10 vikur eftir aðgerð, en að meðaltali tók meðferðin 19 daga fyrir og 4,4 vikur eftir aðgerð. Pessi tímalengd sýklalyfjagjafar er í samræmi við leiðbeiningar European Heart Society (ESC) par sem mælt er með meðferð í 2-6 vikur en tímalengdin ræðst meðal annars af pví hvort um sýkingu í gerviloku sé að ræða eða ekki. ${ }^{5}$

\section{Fylgikvillar}

Tíðni alvarlegra fylgikvilla var 61\% par sem öndunarbilun (43\%) var algengasti fylgikvillinn og par á eftir var drep í hjartavöðva (35\%), en tíðni ræðst mjög af pví hvaða skilmerki eru notuð við skilgreiningu hjartaskaða. Til samanburðar var tíðni alvarlegra fylgikvilla við míturlokuskipti $47 \%$ og hjartadreps $26 \% .{ }^{17}$ Sambærilegar tölur eftir ósæðarlokuskipti voru 33\% og $14 \%$ fyrir hjartadrep. ${ }^{25}$

Tíðni minniháttar fylgikvilla var $64 \%$, par sem gáttatif/-flökt var algengast (56\%). Í íslenskri rannsókn á míturlokuskiptum greindust minniháttar fylgikvillar hjá $70 \%$ sjúklinga og gáttatif/ flökt hjá $23 \%{ }^{26}$ Sambærilegar tölur eftir ósæðarlokuskipti voru $84 \%$ og 77\% sem er hærri tíðni minniháttar fylgikvilla en í okkar rannsókn. ${ }^{25}$ Skýrist pað sennilega af háum aldri sjúklinga við ósæðarlokuskipti.

Enduraðgerð vegna blæðinga er alvarlegur fylgikvilli, hana purfti að framkvæma á fjórðungi sjúklinga. Telst pað hátt hlutfall. Til samanburðar var tíðni enduraðgerða vegna blæðingar eftir míturlokuskipti á Íslandi 15\% og eftir ósæðarlokuskipti á árunum 2002-2006 17\%. ${ }^{17,25}$ Tíðni enduraðgerða vegna blæðinga eftir hjartaaðgerð er kringum $8 \%$ á Íslandi en erlendis er hlutfallið oft $2-5 \%{ }^{27}$ Skýringin er ekki augljós, en ábendingar fyrir enduraðgerð geta verið mismunandi milli stofnana. Sjúklingar í okkar rannsókn voru hugsanlega veikari pegar peir voru teknir til aðgerðar og tíðni fylgikvilla pví hærri en ella. ${ }^{28}$

\section{Dánartíðni og lifun}

Dánartíðni innan 30 daga var 11\%, en einn sjúklingur lést í aðgerð úr losti. Til samanburðar var dánartíðni $9 \% 30$ dögum eftir míturlokuskipti á Íslandi og 6\% eftir ósæðarlokuskipti. Fimm ára lifun í okkar rannsókn reyndist 59\% samanborið við 69\% eftir valaðgerð á míturloku og 78\% eftir ósæðarlokuskipti. ${ }^{1729}$ Í erlendum rannsóknum er 30 daga dánartíðni eftir aðgerð vegna hjartapelsbólgu á bilinu 6-25\% og langtímalifun oftast í kringum $70 \%{ }^{13}$ Svipuðum niðurstöðum var lýst í sænskri rannsókn en par var dánartíðni til lengri og skemmri tíma umtalsvert lægri fyrir sjúklinga sem fóru í aðgerð, en fyrir pá sem aðeins fengu sýklalyfjameðferð. ${ }^{23}$

\section{Veikleikar og styrkleikar rannsóknar}

Veikleiki pessarar rannsóknar er að hún er afturskyggn, en klínískar upplýsingar í sjúkraskrám voru ekki alltaf vel skráðar, sérstaklega í upphafi rannsóknartímabilsins. Annar veikleiki er hversu lítið pýðið er, sem takmarkar styrk við tölfræðilega úrvinnslu. Styrkleiki rannsóknarinnar er sá að hún nær til heillar pjóðar og allar aðgerðir voru gerðar af tiltölulega fáum skurðlæknum á einni stofnun. Einnig voru upplýsingar um eftirfylgd og afdrif sjúklinganna mjög góðar.

\section{Samantekt}

Á rannsóknartímabilinu sem var frá 1997 til 2013 gekkst fimmti hver sjúklingur á Íslandi sem greindist með hjartapelsbólgu undir opna hjartaaðgerð, oftast vegna hjartabilunar sem rakin var til leka í sýktu lokunni. Petta hlutfall hækkar eftir pví sem líður á rannsóknartímabilið. Sökum pess hve veikir pessir sjúklingar eru pegar peir gangast undir aðgerð eru fylgikvillar tíðari en eftir hefðbundnar lokuskiptaaðgerðir. Petta á sérstaklega við um enduraðgerð vegna blæðingar, hjartadrep og gáttaflökt. Pá er 30 daga dánartíðni pessara sjúklinga hærri og langtímalifun lakari en eftir hefðbundnar valaðgerðir á ósæðar- og míturloku. 


\section{Heimildir}

1. Tryggvadóttir EB, Agnarsson UP, Sverrisson JP, porsteinsson SB, Högnason JV, porgeirsson G. Hjartapelsbólga á Íslandi 2000-2009. Nýgengi, orsakir og afdrif. Læknablaðið 2012; 98: 25-30.

2. Eiríksson $\mathrm{BH}$, porgeirsson $\mathrm{G}$, Porsteinsson $\mathrm{SB}$. Hjartapelsbólga á Íslandi 1976-1985. Nýgengi - orsakir afdrif. Læknablaðið 1989; 75: 149-55.

3. Hogevik H, Olaison L, Andersson R, Lindberg J, Alestig $K$. Epidemiologic aspects of infective endocarditis in an urban population. A 5-year prospective study. Medicine 1995; 74: 324-39.

4. Tleyjeh IM, Steckelberg JM. Changing epidemiology of infective endocarditis. Curr Infect Dis Rep 2006; 8: 265-70.

5. Habib G, Hoen B, Tornos P, Thuny F, Prendergast B, Vilacosta I, et al. Guidelines on the prevention, diagnosis, and treatment of infective endocarditis (new version 2009): the Task Force on the Prevention, Diagnosis, and Treatment of Infective Endocarditis of the European Society of Cardiology (ESC). Endorsed by the European Society of Clinical Microbiology and Infectious Diseases (ESCMID) and the International Society of Chemotherapy (ISC) for Infection and Cancer. Eur Heart J 2009; 30: 2369413.

6. Yuh DD VL, Yang S, Doty JR. Textbook of Cardiothoracic Surgery, eBook. 2nd ed. McGraw Hill Education, United States 2014.

7. Mylonakis E, Calderwood SB. Infective endocarditis in adults. N Engl J Med 2001; 345: 1318-30.

8. Bayer AS, Bolger AF, Taubert KA, Wilson W, Steckelberg J, Karchmer AW, et al. Diagnosis and management of infective endocarditis and its complications. Circulation 1998; 98: 2936-48.

9. Lee SH, Kang DR, Uhm JS, Shim J, Sung JH, Kim JY, et al. New-onset atrial fibrillation predicts long-term newly developed atrial fibrillation after coronary artery bypass graft. Am Heart J 2014; 167: 593-600.e1.

10. Cabell CH, Abrutyn E, Karchmer AW. Cardiology patient page. Bacterial endocarditis: the disease, treatment, and prevention. Circulation 2003; 107: e185-7.
11. Anguera I, Quaglio G, Miro JM, Pare C, Azqueta M, Marco F, et al. Aortocardiac fistulas complicating infective endocarditis. Am J Cardiol 2001; 87: 652-4, a10.

12. Castillo JC, Anguita MP, Ramirez A, Siles JR, Torres F, Mesa $\mathrm{D}$, et al. Long term outcome of infective endocarditis in patients who were not drug addicts: a 10 year study. Heart (British Cardiac Society) 2000; 83: 525-30.

13. Prendergast $B D$, Tornos P. Surgery for infective endocarditis: who and when? Circulation 2010; 121: 1141-52.

14. Bloomfield P. Choice of heart valve prosthesis. Heart (British Cardiac Society) 2002; 87: 583-9.

15. Nishimura RA, Otto CM, Bonow RO, Carabello BA, Erwin JP 3rd, Guyton RA, et al. 2014 AHA/ACC guideline for the management of patients with valvular heart disease: a report of the American College of Cardiology/American Heart Association Task Force on Practice Guidelines. J Am Coll Cardiol 2014; 63: e57-185.

16. Noyez L, Kievit PC, van Swieten HA, de Boer MJ. Cardiac operative risk evaluation: The EuroSCORE II, does it make a real difference? Neth Heart J 2012; 20: 494-8.

17. Ragnarsson S, Sigurðsson MI, Danielsen R, Arnórsson P, Guðbjartsson T. Árangur míturlokuskipta á Íslandi. Læknablaðið 2012; 98: 203-9.

18. Chu VH, Park LP, Athan E, Delahaye F, Freiberger T, Lamas C, et al. Association between surgical indications, operative risk, and clinical outcome in infective endocarditis: a prospective study from the International Collaboration on Endocarditis. Circulation 2015; 131: 13140.

19. Habib G. Management of infective endocarditis. Heart 2006; 92: 124-30.

20. Ruttmann E, Willeit J, Ulmer H, Chevtchik O, Hofer D, Poewe W, et al. Neurological outcome of septic cardioembolic stroke after infective endocarditis. Stroke 2006; 37: 2094-9.

21. Correa de Sa DD, Tleyjeh IM, Anavekar NS, Schultz JC, Thomas JM, Lahr BD, et al. Epidemiological trends of infective endocarditis: a population-based study in Olmsted County, Minnesota. Mayo Clin Proc 2010; 85: 422-6.
22. Fernandez Guerrero ML, Gonzalez Lopez JJ, Goyenechea A, Fraile J, de Gorgolas M. Endocarditis caused by Staphylococcus aureus: A reappraisal of the epidemiologic, clinical, and pathologic manifestations with analysis of factors determining outcome. Medicine 2009; 88: $1-22$.

23. Ternhag A, Cederstrom A, Torner A, Westling K. A nationwide cohort study of mortality risk and long-term prognosis in infective endocarditis in Sweden. PloS one 2013; 8: e67519.

24. Weymann A, Borst T, Popov AF, Sabashnikov A, Bowles C, Schmack B, et al. Surgical treatment of infective endocarditis in active intravenous drug users: a justified procedure? J Cardiothor Surg 2014; 9: 58.

25. Ingvarsdóttir IL, Viktorsson SA, Hreinsson K, Sigurðsson MS, Helgadóttir S, Arnórsson P, et al. Lokuskipti vegna ósæðarlokuprengsla á Íslandi 2002-2006: Ábendingar og snemmkomnir fylgikvillar. Læknablaðið 2011; 97: 523-7.

26. Guðmundsdóttir JF, Ragnarsson S, Geirsson A, Danielsen R, Guðbjartsson T. Árangur míturlokuaðgerða á Íslandi 2001-2012. Læknablaðið 2014; 100: 579-84.

27. Smárason NV, Sigurjónsson $\mathrm{H}$, Hreinsson $\mathrm{K}$, Arnórsson P, Guðbjartsson T. Enduraðgerðir vegna blæðinga eftir opnar hjartaskurðaðgerðir. Læknablaðið 2009; 95: 567-73.

28. Moulton MJ, Creswell LL, Mackey ME, Cox JL, Rosenbloom M. Reexploration for bleeding is a risk factor for adverse outcomes after cardiac operations. J Thor Cardiovasc Surg 1996; 111: 1037-46.

29. Viktorsson SA, Ingvarsdóttir IL, Hreinsson K, Sigurðsson MI, Helgadóttir S, Arnórsson $\mathrm{P}$, et al. Lokuskipti vegna ósæðarlokuprengsla á Íslandi 2002-2006: Langtímafylgikvillar og lifun. Læknablaðið 2011; 97: 591-5.

\section{ENGLISH SUMMARY}

\section{Surgical treatment for endocarditis in Iceland 1997-2003}

Ragnheiður M. Jóhannesdóttir¹, Tómas Guðbjartsson ${ }^{1,2}$ Arnar Geirsson ${ }^{1}$

Introduction: The aim of this study was to evaluate the outcomes of operations for endocarditis in Iceland, but such results have not been reported before.

Materials and methods: Retrospective nation-wide study of patients that underwent open-heart surgery for infective endocarditis at Landspitali University Hospital in 1997-2013. Variables were collected from hospital charts. Long-term survival was analysed using Kaplan- Meier methods. Mean follow-up time was 7.2 years.

Results: Out of 179 patients diagnosed with endocarditis, 38 (21\%) underwent open heart surgery. Two patients were excluded due to missing information leaving 36 patients for analysis. The number of operations steadily increased, or from 8 to 21 during the first and last 5 -years of the study period (OR: $1.12,95 \% \mathrm{Cl}: 1.05-1.21, \mathrm{p}=0.002)$. The most common pathogen was S. aureus and $81 \%(29 / 36)$ of the patients had positive blood cultures. Three patients had history of previous cardiac surgery and five had history of intravenous drug abuse. The aortic valve was most often infected ( $72 \%)$, followed by the mitral valve (28\%). The infected valve was replaced in 35 cases 14 with a mechanical prosthesis and 20 with a bioprosthesis. In addition two mitral valves were repaired. Postoperative complications included perioperative myocardial infarction (35\%), respiratory failure (44\%) and reoperation for bleeding $(25 \%)$. Thirty-day mortality was $11 \%$ (4 patients) with 5- and 10 -year survival of $59 \%$ and $49 \%$, respectively.

Conclusion: One out of five patients with endocarditis underwent surgery, most commonly aortic or mitral valve replacement. Outcomes were comparable to other studies. In comparison to elective valve replacement surgery the rate of post-operative complications and 30-day mortality were higher and long-term survival was less favorable. 